Available online at: https://proceeding.researchsynergypress.com/index.php/cpmhs/index

RSF Conference Series: Medical and Health Science

e-ISSN (to be processed) / p-ISSN (to be processed)

Volume 1 Number 1 (2021): 53-59

\title{
Organoleptic Test of Boba Flour Substitution of Pumpkin Seeds High in Fiber and Protein
}

\author{
Maurizka Sabrina Septia ${ }^{1}$, Septa Katmawanti ${ }^{1}$, Supriyadi ${ }^{1}$ \\ ${ }^{1}$ Public Health Department, Universitas Negeri Malang, Indonesia
}

\begin{abstract}
In 2013, the obesity rate in Indonesia for people over the age of 18 was 14.8 percent; by 2018, the obesity rate had risen to $21.8 \%$ (Riskesdas, 2018a). The significant number of fat people in Indonesia is caused by high sugar consumption and low fiber consumption regularly. One hundred grams of pumpkin seeds contain 6 grams of fiber, 30.23 grams of protein, $7.2 \mathrm{mg} / 100$ zinc, polyunsaturated fatty acids, and phytosterols (Nurhasim, Tamrin, and Wahab, 2017). The purpose of this study is to identify the panelists' level of preference for four formulations of pumpkin seed flour boba using assessment factors such as taste, color, texture, and aroma. The procedural model was used in this research and development. This development study utilizes an opinion-based process (Borg and Gall, 1984), which is then modified based on research needs. Organoleptic testing on boba products without added milk drinks on untrained panelists revealed a significant difference in color and texture parameters. There was no significant difference in panelist acceptability of aroma and taste characteristics. The findings of the untrained panelist's appraisal of boba added to a milk companion drink were then presented, revealing significant changes in the color and texture parameters. Furthermore, there were no statistically significant changes in the aroma and taste indices.
\end{abstract}

Keywords: Boba, Pumpkin Seed Flour, Obesity

This is an open access article under the $\mathrm{CC}-\mathrm{BY}-\mathrm{NC}$ license

\section{INTRODUCTION}

In 2013, the obesity rate in Indonesia for people over the age of 18 was 14.8 percent; by 2018, the obesity rate had risen to $21.8 \%$ (Riskesdas, 2018a). Obesity sufferers in East Java province in 2013-2018 with the age of more than 18 years experienced a significant increase. In 2013, it was $8.4 \%$, but by 2018 , it had risen to $22.37 \%$ (Riskesdas, 2018b). The significant number of fat people in Indonesia is due to high sugar consumption and low fiber consumption on a regular basis. In 2018, Indonesians used $11.47 \mathrm{~kg}$ of sugar per person per year, or 32 grams per person per day (USDA, 2017). The young adult age group ( $>19$ years) consumes the highest extra sugar by age, accounting for more than 13 percent of the population (Rosinger et al., 2017).

Obesity is induced not just by excessive sugar consumption but also by a lack of fiber consumption, such as vegetables and fruit. According to a 2013 study conducted by Winastyo and Kumboyono, $62 \%$ of Malang schoolchildren dislike vegetables (Katmawanti, 2017). The daily fiber consumption of Malang City teenagers is $3.19 \mathrm{~g} /$ day, which is much less than the recommended daily fiber consumption of $25 \mathrm{~g} / \mathrm{day}$ (Septiana, Fajar, and Catur, 2018). According to the SKMI analysis, fruit and vegetable consumption in

Corresponding author

Maurizka Sabrina Septia , maurizkasabrina@gmail.com

DOI: (to be processed)

Research Synergy Foundation 
Indonesia remains low at $9.71 \%$, with the adolescent age group dominating this figure (Hermina and Prihatini, 2016).

Cucurbita moschata seeds, also known as pumpkin seeds, are a good source of protein and fiber in Indonesia. According to BPS data, pumpkin production in Indonesia reached 942,928 kg in 2015, while it fell slightly to 805,173 kg in 2016 (BPS, 2016). Cucurbita moschata seeds, sometimes known as pumpkin seeds, are abundant in fiber, protein, minerals, and antioxidants. Pumpkin seeds contain 6 grams of fiber and 30.23 grams of protein per 100 grams, as well as $7,2 \mathrm{mg}$ of zinc per 100 grams, double unsaturated fatty acids, and phytosterols. Amino acids, Mg (magnesium), vitamin E (tocopherol), carotenoids, cryptoxanthin, monocyclic sesquiterpenoids, and trypsin inhibitors that can inhibit peroxides that turn into free radicals and oxidize unsaturated fatty acids in cell membranes are also beneficial to the body (Nurhasim, Tamrin, and Wahab, 2017).

Cucurbita moschata seeds, also known as pumpkin seeds, have the advantage of being able to be transformed into pumpkin seed flour, which can improve usability and make it easier to process into goods with high nutritional content that can become popular. Boba is a popular product among Indonesian youth right now. Boba is generally made from tapioca flour. This is a factor in the development of boba with the addition of pumpkin seed flour, which is expected to be a product that can be consumed and is beneficial to health, particularly for obese people. Boba can be made more nutritious by adding pumpkin seed flour, which contains fiber. Adequate fiber consumption can lower the risk of obesity.

This study includes both general and specialized objectives. The overall goal of this study is to create boba by using pumpkin seed flour (Cucurbita moschata) as a high protein and fiber drink topping. At the same time, the specific goal of this study was to identify the panelists' organoleptic preference level on four formulations of pumpkin seed flour boba with assessment factors such as taste, color, texture, and aroma.

\section{LITERATURE REVIEW Pumpkin}

According to Zufami (2014) in (Fadhilah et al., 2018), pumpkin (Cucurbita moschata) is a plant source of food with high nutritional content and fine fiber, making it easy to digest. Pumpkin plants are members of the Cucurbitaceae family, which includes melons (Cucumis melo) and cucumbers (Cucumis sativum). The pumpkin fruit is made up of two layers: a hard outer skin layer and a layer of fruit flesh that serves as a storage area for nourishment. Yellow pumpkins come in "nokor" (flat round and grooved), oval-shaped, and long cup-shaped varieties. Pumpkin seeds are found in the cavity covered by mucus and fiber in the center of the fruit flesh. The seeds have a flat form with a tapering tip (Fadhilah et al., 2018).

\section{Pumpkin Seed Composition}

Pumpkin seeds are high in macronutrients (magnesium, phosphorus, and calcium) and low in micronutrients (calcium, manganese, copper, and zinc). Pumpkin seeds can be utilized as a good food supplement because they are high in nutritious value; also, pumpkin is inexpensive (Devi et al., 2018).

\section{Pumpkin Seeds Health Benefits}

Pumpkin seeds are well-known for their nutritional value. Furthermore, pumpkin seeds can be used to treat joint inflammatory illnesses and prostate cancer (Devi et al., 2018). pumpkin seed oil (Cucurbita moschata) also includes chromium, a mineral known to play a role in carbohydrate metabolism, with the best chromium absorption at 40 mcg per serving (Junita et al., 2017). 


\section{RESEARCH METHODOLOGY}

\section{Research and Development Model}

The procedural model was applied to conduct this research. The procedural model is a descriptive model that depicts the actions that must be taken in order to produce a product (Silalahi, 2018). The procedure utilized in this research and development is based on opinion (Borg and Gall, 1984), and it is then modified based on the research demands.

\section{Materials and tools}

Tapioca flour, pumpkin seed flour, sugar, water, and food coloring were the ingredients used in this research. Among the tools used were a blender, basin, Teflon, sieve, spatula, pan, knife, and a memmert oven.

\section{Making pumpkin seed flour}

The initial step is to select pumpkin seeds. Pumpkin seeds with no skin should be utilized to avoid a bitter taste. Furthermore, pumpkin seeds without skin are mashed in a blender for 8-10 minutes to make a powder, which is then filtered through a sieve with a mesh size of 60 to get a homogeneous particle size and smooth texture. The pumpkin seeds are then stored at a room temperature of 28-30 degrees Celsius (Diska, Anjelina, 2019).

\section{Making Boba}

Weighing the ingredients according to the formulation is the first step in creating boba with a pumpkin seed flour substitute. Each formulation contains the same amount of water and sugar, weighing 20 and 13 grams, respectively. The pumpkin seed flour and tapioca flour ingredients were then adjusted for each formulation F0 (0g:45g), F1 (4.5g:40.5g), F2 (9g:36g), and F3 (13.5g:31.5g). After weighing everything, add the water and sugar to the Teflon and cook until the sugar is melted, then add the flour little by little, constantly stirring, until the dough becomes smooth and ready to shape. After shaping the dough into a round, it will be boiled for 30 minutes or until the surface becomes transparent.

\section{Boba's Formula}

This study's boba formula concentrated on variations in the size of pumpkin seed flour utilized, with four treatments: $0 \%, 10 \%, 20 \%$, and $30 \%$. In the production of boba, this concentration of pumpkin seed flour will replace the use of tapioca flour.

Table 1. Boba formula

\begin{tabular}{ccccc}
\hline Ingredients & \multicolumn{4}{c}{ Boba's Formula (g) } \\
\cline { 2 - 5 } & F0 & F1 & F2 & F3 \\
\hline Pumpkin Seed Flour & 0 & 4,5 & 9 & 13,5 \\
Tapioca Starch & 45 & 40,5 & 36 & 31,5 \\
Palm sugar & 13 & 13 & 13 & 13 \\
Water & 20 & 20 & 20 & 20 \\
food coloring (black) & 0,67 & 0,67 & 0,67 & 0,67 \\
\hline
\end{tabular}

\section{Organoleptic Test Assessment}

Organoleptic testing was carried to examine the panelists' response to boba products. Color, aroma, taste, and texture are among the parameters assessed in the organoleptic implementation (Noviyanti et 
al., 2016). The organoleptic test was performed using a hedonic scale or a scale to evaluate the level of preference consisting of 5 scales: very much like (5), very like (4), like (3), somewhat like (2), dislike (1).

\section{FINDINGS AND DISCUSSION}

\section{Results}

\section{Trained Panelists}

The average value of organoleptic results from trained panelists on boba with pumpkin seed flour substitution is shown below.

Table 2. The Average Score of The Organoleptic Test of Boba Flour Substitute of Pumpkin Seed Flour Trained Panelists

\begin{tabular}{ccccc}
\hline Formulation & \multicolumn{4}{c}{ Average Score } \\
\cline { 2 - 5 } & Color & Aroma & Texture & Taste \\
\hline F0 & 4,33 & 4,33 & 4,00 & 4,33 \\
F1 & 2,67 & 3,67 & 3,33 & 2,67 \\
F2 & 2,67 & 3,67 & 3,67 & 3,00 \\
F3 & 3,33 & 4,33 & 4,00 & 4,00 \\
\hline
\end{tabular}

According to table 2, the highest color parameter assessment findings were discovered in the F0 formulation, namely 4.33, and the lowest in the F1 and F2 formulations, respectively 2,67. The F0 and F3 formulations had the highest aroma rating, 4,33, while the F1 and F2 formulations received the lowest, 3,67. Meanwhile, the highest texture assessment was in the F0, and F3 formulations, namely 4.00, and the lowest was in the F1 formulation, namely 3,33. The F0 formulation received the highest rating from the panelists, with a score of 4,33, and the F1 formulation received the lowest rating, with a score of 2,67. Friedman test analysis on the color parameter trial of trained panelists, with a p-value of 0,218 , revealed that there was no significant difference in panelist acceptability between the four formulations. According to the aroma of the Friedman test results, the p-value of 0.644 indicates that there was no significant difference in the panelists' acceptability between the four formulations. The Friedman test findings for texture parameters have a p-value of 0.861 , showing that there was no significant difference in panelist approval between the four formulations. The taste parameter has a Friedman test result with a p-value of 0.157 , showing that there was no significant difference in panelist approval between the four formulae.

\section{Untrained Panelists (Without Milk)}

The average value of untrained panelists' organoleptic test results on boba with pumpkin seed flour substitution is as follows.

Table 3. The Average Score of Untrained Panelists' Organoleptic Test of Pumpkin Seed Flour Substitute (Without Milk)

\begin{tabular}{ccccc}
\hline Formulation & \multicolumn{4}{c}{ Average Score } \\
\cline { 2 - 5 } & Color & Aroma & Texture & Taste \\
\hline F0 & 3,33 & 2,77 & 2,87 & 2,27 \\
F1 & 2,47 & 2,50 & 2,77 & 2,07 \\
F2 & 2,70 & 2,80 & 2,27 & 2,63 \\
F3 & 2,37 & 2,50 & 2,20 & 2,53 \\
\hline
\end{tabular}


According to table 3, the color parameter of the control formulation (F0) had the highest average score of 3,33 out of the 30 panelists that assessed boba with pumpkin seed flour substitution. F3 has the lowest average value, with a score of 2,37 . The aroma parameter was rated highest by the panelists in the F2 formulation, with a score of 2,80, and lowest in the F1 and F3 formulations, with a score of 2,50. The F0 formulation has the highest texture rating of 2,87, while the F3 formulation has the lowest texture rating of 2,20. The F2 formulation had the highest taste rating of 2.63 , while the F1 formulation received the lowest, namely 2,07. The color and texture parameters in the Friedman test show p-values of 0.000 and 0.004 , respectively, indicating there was a significant difference in panelist approval. The aroma and taste parameters exhibit p-values of 0.457 and 0.339 , respectively, showing there was no significant difference in the panelists' acceptance of the four formulations.

\section{Untrained Panelists (Milk)}

Table 4 shows the results of an organoleptic assessment of boba products with pumpkin seed flour substitution by untrained panelists.

Tabel 4. The Average Score of Untrained Panelists' Organoleptic Test of Pumpkin Seed Flour Substitute (With Milk)

\begin{tabular}{ccccc}
\hline Formulation & \multicolumn{4}{c}{ Average Score } \\
\cline { 2 - 5 } & Color & Aroma & Texture & Taste \\
\hline F0 & 3,43 & 3,13 & 3,50 & 3,57 \\
F1 & 3,37 & 3,00 & 3,53 & 3,67 \\
F2 & 2,93 & 2,97 & 3,17 & 3,60 \\
F3 & 2,80 & 2,93 & 2,70 & 3,17 \\
\hline
\end{tabular}

Table 4 displays the organoleptic assessment results of 30 untrained panelists for boba products with complimentary milk drinks, specifically $\mathrm{F} 0$ and $\mathrm{F} 1$, which are the most favored formulations with high average values for each parameter. Friedman test results on each parameter, specifically the color and texture of the Friedman test results, had p-values of 0.001 and 0.005 , showing a significant difference in panelist approval. The Friedman test results in aroma and taste have p-values of 0.496 and 0.107 , respectively, showing that there was no significant difference in panelist approval amongst the four recipes.

\section{Discussion}

The panelists' organoleptic test findings from the four boba formulations with pumpkin seed flour substitution based on four organoleptic parameters, namely color, aroma, texture, and taste, revealed that all formalizations were acceptable. For boba without the addition of milk, the average score of the organoleptic test was 2,5-2,8, putting it in the "somewhat like" category. Meanwhile, the panelists enjoyed boba with the addition of a supplementary drink, namely milk. The average score of boba with milk is 2,93,4 or in the category of "somewhat like".

This is supported by statistical data on boba without complimentary drinks, which indicates no significant variations in the aroma and taste parameters. In the meantime, the color and texture parameters had a significant impact. The statistical results on boba with milk drinks reveal that there is no difference in taste and aroma parameters. Meanwhile, the color and texture parameters have a significant impact. Based on 
the highest overall evaluation score for boba without supplementary drinks, namely the control formulation (F0). Meanwhile, the control formulation (F0) and the first formulation (F1) with a concentration of 4.5 grams of pumpkin seed flour have the highest overall score for boba with a supplementary beverage. It can be inferred from this study that when boba was made with pumpkin seed flour substitution, four formulations were obtained in a row as much as $0,4,5,9,13.5$ grams with a combination of tapioca flour in rows 45, 40.5, 36, 31, 5 grams, 13 grams of sugar, and 20 grams of water.

\section{CONCLUSION AND FURTHER RESEARCH}

The findings of the organoleptic test revealed that there was no significant difference in the panelists' acceptance of all parameters based on the judgment of trained panelists on boba products. The results of an organoleptic test on boba products without additional milk drinks conducted by untrained panelists revealed a significant variation in color and texture parameters. Meanwhile, there was no significant change in the panelists' acceptance of the aroma and taste parameters. The results of the untrained panelists' evaluation of the boba coupled with milk as a companion drink, notably significant variations in the color and texture parameters, were then presented. And there is no significant difference in the aroma and taste parameters.

\section{REFERENCES}

Borg, W. R. and Gall, M. D. (1984) 'Educational Research: An Introduction, British Journal of Educational Studies, p. 274. DOI: 10.2307/3121583.

BPS (2016) 'Statistik Tanaman Sayuran dan Buah-buahan Semusim'.

Diska, Anjelina, S. (2019) 'Pengembangan Cookies dari Tepung Labu Kuning, Tepung Biji Labu Kuning, Tepung Beras, dan Tepung Oncom Hitam yang Mengandung Omega 3', Journal of Chemical Information and Modeling, 53(9), pp. 1689-1699. doi: 10.1017/CB09781107415324.004.

Fadhilah, A. et al. (2018) 'Prosiding Seminar Nasional Biologi dan Pembelajarannya Universitas Negeri Medan, 12 Oktober 2018 ISSN 2656-1670'.

Hermina and Prihatini, S. (2016) 'Gambaran Konsumsi Sayur dan Buah Penduduk Indonesia dalam Konteks Gizi Seimbang: Analisis Lanjut Survei Konsumsi Makanan Individu (SKMI) 2014', Buletin Penelitian Kesehatan, 44(3), pp. 4-10. doi: 10.22435/bpk.v44i3.5505.205-218.

Katmawanti, S. (2017) 'Survey dan Analisis'.

Nurhasim, A., Tamrin and Wahab, D. (2017) 'Pengembangan Susu Nabati Dari Filtrat Biji Labu Kuning (Cucurbita Moschata) dan Filtrat Ubi Jalar (Impomoea Batatas L.)', Sains dan Teknologi Pangan, 2(4), pp. 648-656.

Riskesdas (2018a) 'Hasil Utama Riset Kesehatan Dasar (RISKESDAS)', Journal of Physics A: Mathematical and Theoretical, 44(8), pp. 1-200. DOI: 10.1088/1751-8113/44/8/085201.

Riskesdas (2018b) Hasil Utama RISKESDAS 2018 Provinsi Jawa Timur.

Rosinger, A. et al. (2017) 'Sugar-sweetened Beverage Consumption Among U.S. Youth, 20112014', NCHS data brief, (271), pp. 1-8.

Septiana, P., Fajar, A. and Catur, S. (2018) 'Konsumsi Junk food dan Serat pada Remaja Putri Overweight dan Obesitas yang Indekos Junk food and Fiber Consumption among Overweight and Obese Young Women Living in Boarding House', 30(1), pp. 61-67. 
Silalahi, A. (2018) 'Development Research (Penelitian Pengembangan) dan Research \& Development (Penelitian \& Pengembangan) Dalam Bidang Pendidikan/Pembelajaran', Research Gate, (June), pp. 1-13. doi: 10.13140/RG.2.2.13429.88803/1.

USDA (2017) 'Indonesia Sugar Annual Report 2017', pp. 1-9. Available at: https://gain.fas.usda.gov/Recent GAIN Publications/Sugar Annual_Jakarta_Indonesia_4-132017.pdf. 